\title{
THE VALUE OF DISTRIBUTED REPETITIONS IN ROTE LEARNING.
}

\section{By NELLIE L. PERKINS.}

\author{
I. Introductory. \\ II. Experimental methods. \\ III. Experimental data. \\ IV. Conclusions.
}

1. These experiments were carried out during the year 1911-12 at the Psychological Laboratory of the University of Michigan, under the direction of Professor Pillsbury. The work of Ebbinghaus ${ }^{1}$ had shown the decided advantage of distributing repetitions over several days. The studies of Jost ${ }^{2}$ confirmed the result and proved that it was not merely due to the fatigue arising in the case of accumulated repetitions. Dearborn ${ }^{3}$ reported some results obtained in class experiments which suggested that practice once a day with a substitution test was somewhat better than practice twice a day. While my own experiments were in progress, Starch ${ }^{4}$ published work with a substitution test which indicated that ter minutes at a time twice a day for six days is a better distribution of one hundred and twenty minutes than more condensed arrangements.

Since the first draft of this paper was written, Pyle ${ }^{5}$ has published an article in which he distinguishes sharply between length and frequency of periods. He does not, however, sufficiently recognise that the best interval for one length of period may not be the same as the best interval for a different length of period. He used another form of substitution test and concluded that "in habit formation an adult can

1 H. Ebbinghaus, Über das Gedächtnis, 1885.

2 A. Jost, "Die Associations-festigkeit in ihrer Abhängigkeit von der Verteilung der Wiederholungen," Ztsch. f. Psychol. xiv. 436.

3 W. F. Dearborn, "Experiments in Learning," J. of Educ. Psychol., 1910, I. 373-388.

4 D. Starch, "Periods of Work in Learning," ibid., 1912, 1II. 209-213.

5 W. H. Pyle, "Economical Learning," ibid., 1913, IIr. 148-158. 


\section{Value of Distributed Repetitions in Rote Learning}

practice profitably for something like 30 minutes daily." "It is quite probable that in the later stages of habituation, the length of practice period could be shortened and the interval lengthened with practically as much return."

My own experiments were designed to ascertain how much further in the distribution of readings one might go than Jost had gone before a limit would be reached in learning nonsense syllables. The best arrangement of readings involves two questions,- - how many repetitions should be used at each period, and, for each number of repetitions per period, what interval between the periods is best.

2. Our apparatus consisted of a modified Wirth memory machine, a Hipp chronoscope, and a voice key. The make-and-break-circuit arrangement was used. The main change in the Wirth apparatus was in the cylinder. A new all-metal cylinder made with moveable contacts was substituted for the original one ${ }^{1}$. The memory apparatus was run either by an electric clock or a metronome, making the response constant. All the experiments were given exactly alike and at the same time of day. Four subjects were used. All of them had had long laboratory experience and were accustomed to giving introspections. They had worked on memory investigations before. They learned with approximately the same ease and, while their methods varied, the per cent. saved in each case ranged about the same. The Scoring (Treffer) Method (in a slightly modified form) was the only one used.

Each series for learning was made up of fourteen syllables grouped in pairs. Each set was given sixteen repetitions, either one, two, four, or eight at a sitting. The intervals between sittings were either one, two, three or four days. There were fourteen spaces on the memory disc. A pair of syllables was slipped into every other space, so that syllables and blanks alternated. A three-second exposure was allowed for each space. Thus each syllable was in view three seconds and was followed by a three-second wait. The subject read them without speaking. The order of the syllables in the first reading determined the order throughout the experiment; that is, if the paired syllables were read in the order $1,2,3,4,5,6,7$, every succeeding repetition, either for learning or testing, maintained the same order. The only difference between the experiments was the order of distribution of readings for learning. The test occurred two weeks after the last exposure. This is worth emphasis, for much of the work on memory has been done with a

1 J. F. Shepard and H. M. Fogelsonger, "Inhibition," Psychol. Rev., 1913, xx. 292. 
shorter interval between lcarning and testing, and in many cases it is questionable whether the same laws hold, at least uncomplicated by others, for short and long waits. We have some evidence that divided repetitions are relatively much more effective when tests are made after longer periods than when tested after twenty-four hours. The experiments were carried on over a period of ten months. If often happened that several series fell due on the same day, e.g. where a subject was learning one series which was given one repetition every day for sixteen days and another series which was given one repetition every second day. In this case the different series were given with an interval of twenty minutes between them.

The series were not given in a definite order, but each subject was learning at least three series and never more than five series at a time. These were so arranged that there were never more than twelve nor less than six readings a day, e.g. a subject might be learning four seriesone given two readings a day for eight days, a second given four readings every other day for eight days, a third given two readings every third day for twenty-four days, and a fourth given eight readings every other day for three days-in which case the readings for each day would be as follows :

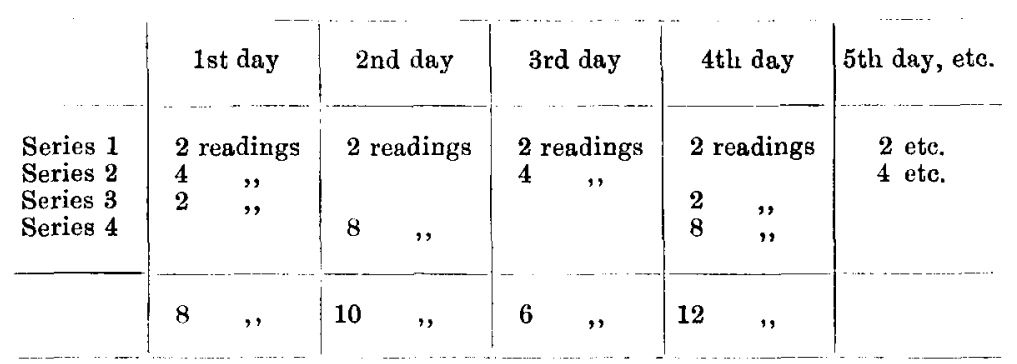

As the readings for each series were completed new series were added according to the above regulation, so that there was continuous learning and testing for ten months-the object being to keep each day as nearly like the preceding days as was possible.

3. Although the subject read the syllables silently in learning, both visual and centrally aroused motor-auditory cues may have played a part in the association process. Accordingly it is sometimes difficult to evaluate an association. One letter may be substituted for another of the same sound in the subject's reply; still the result is correct in an auditory sense. (In making the response the subject was required to 


\section{Value of Distributed Repetitions in Rote Learning}

pronounce the syllable and then spell it.) Accordingly for completeness, two calculations of the per cent. correct were made. In the one, the 'auditory recall' of Table I, a reply was given full value if it was correct in sound, e.g. sak is equivalent to sac. If two letters were correct in sound it was given two-thirds value. If only one letter was correct, since this often happens by accident, it was given no credit. In the other calculation, the 'visual recall' of Table I, credit was given only when a letter was exact, regardless of similar sound. A summary of the results is given in the following table, which shows the results for auditory and visual recall.

\section{TABLE I.}

\begin{tabular}{|c|c|c|c|c|c|c|c|}
\hline & & & & $\begin{array}{l}\text { No. of } \\
\text { Series }\end{array}$ & $\begin{array}{l}\text { Per cent. } \\
\text { correct }\end{array}$ & $\underset{\text { Recall }}{\text { Auditory }}$ & $\begin{array}{l}\text { correct } \\
\text { gh }\end{array}$ \\
\hline $\begin{array}{l}1 \\
1 \\
1 \\
1\end{array}$ & $\begin{array}{l}\text { ding e } \\
\text { ", } \\
\text { ", }\end{array}$ & $\begin{array}{l}\text { ver. } \\
\text {," }\end{array}$ & $\begin{array}{l}\text { day } \\
\text { other day } \\
\text { 3rd , } \\
\text { 4th ,, }\end{array}$ & $\begin{array}{r}10 \\
5 \\
4 \\
4\end{array}$ & $\begin{array}{l}79 \\
72 \\
82 \\
68\end{array}$ & $\begin{array}{l}83 \\
79 \\
82 \\
74\end{array}$ & $\begin{array}{l}74 \\
65 \\
82 \\
56\end{array}$ \\
\hline $\begin{array}{l}2 \\
2 \\
2 \\
2\end{array}$ & $\begin{array}{l}\text { adings } \\
\text { ", } \\
\text { ", }\end{array}$ & ", & $\begin{array}{l}\text { day } \\
\text { other day } \\
\text { 3rd ", } \\
\text { 4th ", }\end{array}$ & $\begin{array}{r}11 \\
8 \\
6 \\
5\end{array}$ & $\begin{array}{l}43 \\
78 \\
65 \\
45\end{array}$ & $\begin{array}{l}54 \\
80 \\
68 \\
53\end{array}$ & $\begin{array}{l}39 \\
74 \\
56 \\
33\end{array}$ \\
\hline $\begin{array}{l}4 \\
4 \\
4 \\
4\end{array}$ & $\begin{array}{l}\text {," } \\
\text { ", }\end{array}$ & $\begin{array}{l}\text { ", } \\
\text { ", }\end{array}$ & $\begin{array}{l}\text { day } \\
\text { other day } \\
\text { 3rd ," } \\
\text { 4th ," }\end{array}$ & $\begin{array}{r}9 \\
10 \\
11 \\
14\end{array}$ & $\begin{array}{l}25 \\
33 \\
29 \\
41\end{array}$ & $\begin{array}{l}28 \\
35 \\
30 \\
47\end{array}$ & $\begin{array}{l}24 \\
25 \\
23 \\
30\end{array}$ \\
\hline $\begin{array}{l}8 \\
8 \\
8 \\
8\end{array}$ & $\begin{array}{l}", \\
", \\
",\end{array}$ & $\begin{array}{l}", \\
",\end{array}$ & $\begin{array}{l}\text { day } \\
\text { other day } \\
\text { 3rd ," } \\
\text { 4th ," }\end{array}$ & $\begin{array}{l}10 \\
13 \\
10 \\
12\end{array}$ & $\begin{array}{r}9 \\
16 \\
11 \\
17\end{array}$ & $\begin{array}{l}14 \\
20 \\
13 \\
24\end{array}$ & $\begin{array}{r}4 \\
10 \\
5 \\
8\end{array}$ \\
\hline
\end{tabular}

Reading from left to right we see that there were ten instances of sets of seven-paired syllables given one reading a day through sixteen days and tested two weeks after the last exposure. In the test $79 \%$ of the responses were correct both auditorily and visually, meaning by this that the subject pronounced and spelled the syllable as it was given when learned, $83 \%$ were auditorily correct, though they may have been visually incorrect, that is, the subject gave the right sound but spelled the syllables incorrectly, while only $74 \%$ of the responses were visually correct,-which shows that the subject had used motor-auditory cues 
when learning, although unconsciously-for it is in these terms that the responses were made. There were many instances where the syllables might have been spelled several ways and still have the same sound, e.g. sac, saq, sak. In these cases it often happened that the subject could give the correct sound, but had forgotten how it was spelled.

The results for the different subjects are shown in Tables II-V. Each table shows the number of cases, the average reaction times, and the per cent. correct for each variety of test. A part of the reaction times was not obtained with $\mathrm{Pk}$., and several varieties of tests were omitted with $\mathrm{W}$. and $\mathrm{M}$. This is indicated by dashes.

TABLE II. Subject Pk.

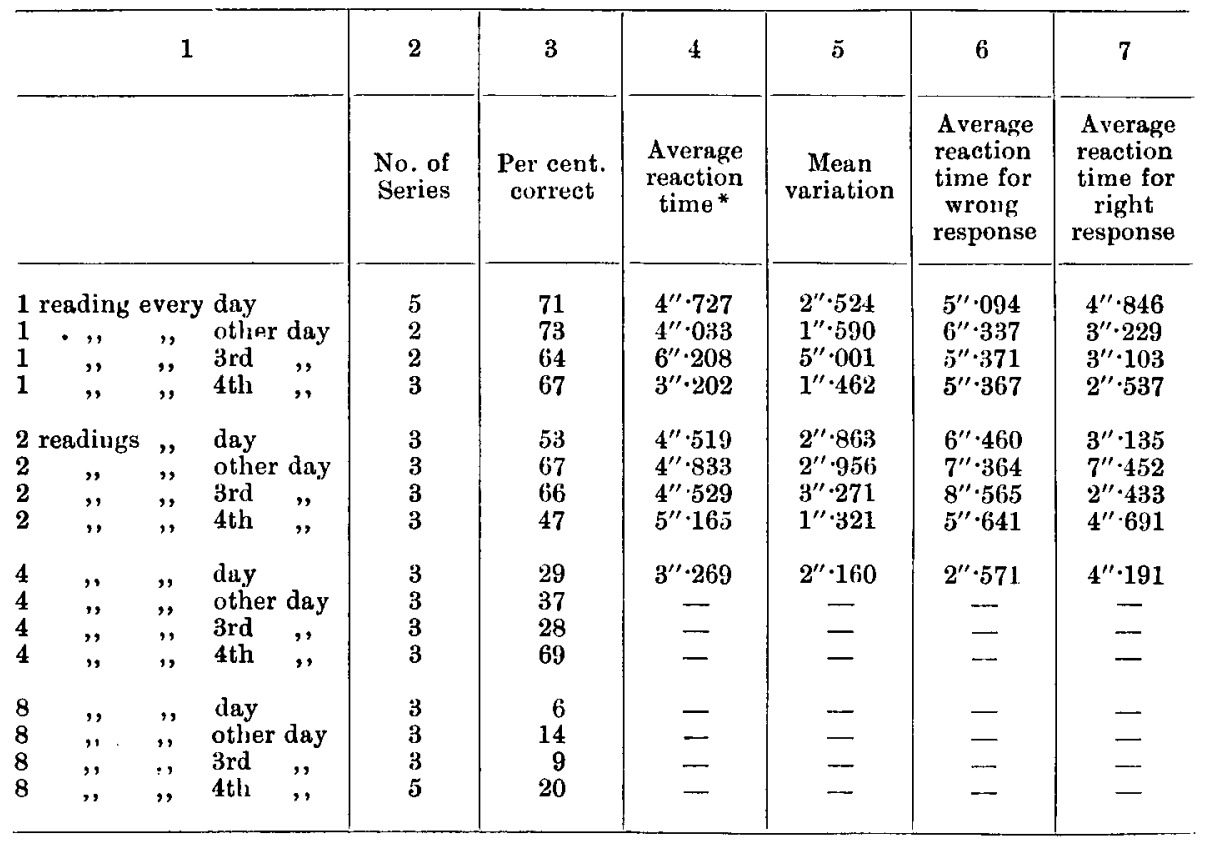

- The average reaction time was computed by finding the average time for all responses, which in this case include both right and wrong responses and what in the discussion is called 'giving up,' that is, when the subject could not recall the syllable, and the response was 'don't know, the time always being recorded just as if he had given a syllable. As there is no discussion of the reaction time for 'giving up,' it is not included in the tables except in so far as it has influenced the time given in Columns 4 headed Average Reaction Time. This accounts for the difference between the average reaction time given in the tables and that which takes into consideration only the average time for right and wrong responses. 


\section{Value of Distributed Repetitions in Rote Learning}

In nearly all cases with each subject the reaction time for a wrong response will be found to be longer than that for a correct response. (Compare Columns 6 and 7 in the tables.) In most results there was a feeling of certainty with the correct responses and they were given at once, whereas there was dissatisfaction when the wrong response was given which made the subject hesitate before she responded.

TABLe III. Subject $A$.

\begin{tabular}{|c|c|c|c|c|c|c|c|c|c|}
\hline & \multicolumn{3}{|c|}{1} & \multirow{2}{*}{$\begin{array}{c}2 \\
\text { No. of } \\
\text { Series }\end{array}$} & \multirow{2}{*}{$\begin{array}{c}3 \\
\begin{array}{c}\text { Per cent. } \\
\text { correct }\end{array}\end{array}$} & \multirow{2}{*}{$\begin{array}{c}4 \\
\\
\begin{array}{c}\text { Average } \\
\text { reaction } \\
\text { time }\end{array}\end{array}$} & \multirow{2}{*}{$\frac{5}{\text { Mean }}$} & \multirow{2}{*}{$\begin{array}{c}6 \\
\text { Average } \\
\text { reaction } \\
\text { time for } \\
\text { wrong } \\
\text { response }\end{array}$} & \multirow{2}{*}{$\begin{array}{c}7 \\
\text { Average } \\
\text { reaction } \\
\text { time for } \\
\text { right } \\
\text { response }\end{array}$} \\
\hline & & & & & & & & & \\
\hline $\begin{array}{l}1 \\
1 \\
1 \\
1\end{array}$ & $\begin{array}{l}\text { ding } \mathrm{e} \\
, " \\
, " \\
",\end{array}$ & $\begin{array}{l}\text { very } \\
\text {," } \\
\text { ", }\end{array}$ & $\begin{array}{l}\text { day } \\
\text { other day } \\
\text { 3rd ", } \\
\text { 4th ", }\end{array}$ & $\begin{array}{l}1 \\
2 \\
1 \\
1\end{array}$ & $\begin{array}{r}95 \\
57 \\
100 \\
71\end{array}$ & $\begin{array}{l}1^{\prime \prime} \cdot 799 \\
2^{\prime \prime} \cdot 501 \\
0^{\prime \prime} \cdot 998 \\
1^{\prime \prime} \cdot 856\end{array}$ & $\begin{array}{l}0^{\prime \prime} \cdot 371 \\
1^{\prime \prime} \cdot 761 \\
0^{\prime \prime} \cdot 392 \\
0^{\prime \prime} \cdot 751\end{array}$ & $\begin{array}{c}6^{\prime \prime} \cdot 873 \\
\overline{2^{\prime \prime} \cdot 741}\end{array}$ & $\begin{array}{l}1^{\prime \prime} \cdot 799 \\
1^{\prime \prime} \cdot 392 \\
0^{\prime \prime} \cdot 998 \\
1^{\prime \prime} \cdot 501\end{array}$ \\
\hline $\begin{array}{l}\mathbf{2} \\
\mathbf{2} \\
\mathbf{2} \\
\mathbf{2}\end{array}$ & $\begin{array}{l}\text { dings } \\
", \\
",\end{array}$ & $\begin{array}{l}\text { ", } \\
", \\
",\end{array}$ & $\begin{array}{l}\text { day } \\
\text { other day } \\
\text { 3rd ", } \\
\text { 4th ", }\end{array}$ & $\begin{array}{l}2 \\
1 \\
2 \\
1\end{array}$ & $\begin{array}{r}7 \\
71 \\
73 \\
42\end{array}$ & $\begin{array}{c}1^{\prime \prime} \cdot 783 \\
2^{\prime \prime} \cdot 346 \\
1^{\prime \prime} \cdot 603 \\
-\end{array}$ & $\begin{array}{c}0^{\prime \prime} \cdot 815 \\
1^{\prime \prime} \cdot 117 \\
0^{\prime \prime} \cdot 679 \\
-\end{array}$ & $\begin{array}{c}1^{\prime \prime} \cdot 272 \\
3^{\prime \prime} \cdot 910 \\
3^{\prime \prime} \cdot 976 \\
-\end{array}$ & $\begin{array}{c}0^{\prime \prime} \cdot 926 \\
1^{\prime \prime} \cdot 721 \\
1^{\prime \prime} \cdot 208 \\
-\end{array}$ \\
\hline $\begin{array}{l}4 \\
4 \\
4 \\
4\end{array}$ & $\begin{array}{l}", \\
", \\
",\end{array}$ & $\begin{array}{l}\text { ", } \\
, " \\
",\end{array}$ & $\begin{array}{l}\text { day } \\
\text { other day } \\
\text { 3rd ," } \\
\text { 4th ", }\end{array}$ & $\begin{array}{l}1 \\
2 \\
2 \\
2\end{array}$ & $\begin{array}{r}42 \\
0 \\
14 \\
37\end{array}$ & $\begin{array}{l}4^{\prime \prime} \cdot 442 \\
3^{\prime \prime} \cdot 918 \\
2^{\prime \prime} \cdot 779 \\
3^{\prime \prime} \cdot 240\end{array}$ & $\begin{array}{c}4^{\prime \prime} \cdot 225 \\
1^{\prime \prime} \cdot 817 \\
0^{\prime \prime} \cdot 877 \\
-\end{array}$ & $\begin{array}{l}8^{\prime \prime} \cdot 128 \\
3^{\prime \prime} \cdot 918 \\
2^{\prime \prime} \cdot 761 \\
5^{\prime \prime} \cdot 141\end{array}$ & $\begin{array}{c}1^{\prime \prime} \cdot 982 \\
- \\
2^{\prime \prime} \cdot 993 \\
2^{\prime \prime} \cdot 289\end{array}$ \\
\hline $\begin{array}{l}8 \\
8 \\
8 \\
8\end{array}$ & ", & $\begin{array}{l}", \\
", \\
",\end{array}$ & $\begin{array}{l}\text { day } \\
\text { other day } \\
\text { 3rd , } \\
\text { 4th ," }\end{array}$ & $\begin{array}{l}1 \\
1 \\
1 \\
1\end{array}$ & $\begin{array}{r}0 \\
28 \\
23 \\
0\end{array}$ & $\begin{array}{l}4^{\prime \prime} \cdot 985 \\
6^{\prime \prime} \cdot 021 \\
2^{\prime \prime} \cdot 143 \\
5^{\prime \prime} \cdot 262\end{array}$ & $\begin{array}{l}1^{\prime \prime} \cdot 228 \\
2^{\prime \prime} \cdot 440 \\
0^{\prime \prime} \cdot 846 \\
1^{\prime \prime} \cdot 701\end{array}$ & $\begin{array}{c}4^{\prime \prime} \cdot 985 \\
6^{\prime \prime} \cdot 444 \\
-\overline{5^{\prime \prime} \cdot 262}\end{array}$ & $\begin{array}{c}-\overline{-} \\
4^{\prime \prime} \cdot 961 \\
2^{\prime \prime} \cdot 143 \\
-\end{array}$ \\
\hline
\end{tabular}

Reading from left to right-as in Table I-we see that subject $\mathrm{Pk}$. learned five sets of seven-paired syllables given one reading every day through sixteen repetitions and was tested two weeks after the last exposure. In the test she recalled $71 \%$ of the syllables, the average reaction time being 4.727 seconds with a mean variation of 2.524 seconds. The results for each set may be followed in the same way, and comparisons made by running down the percentages correct for each set in Column 3.

Table VI gives the summary of all results and is to be read from left to right in the same way as the preceding tables were read.

In general, it will be observed that less is recalled when the readings are given every day than when a certain interval, varying from one to 
N. L. Perkins

Tabie IV. Subject $W$.

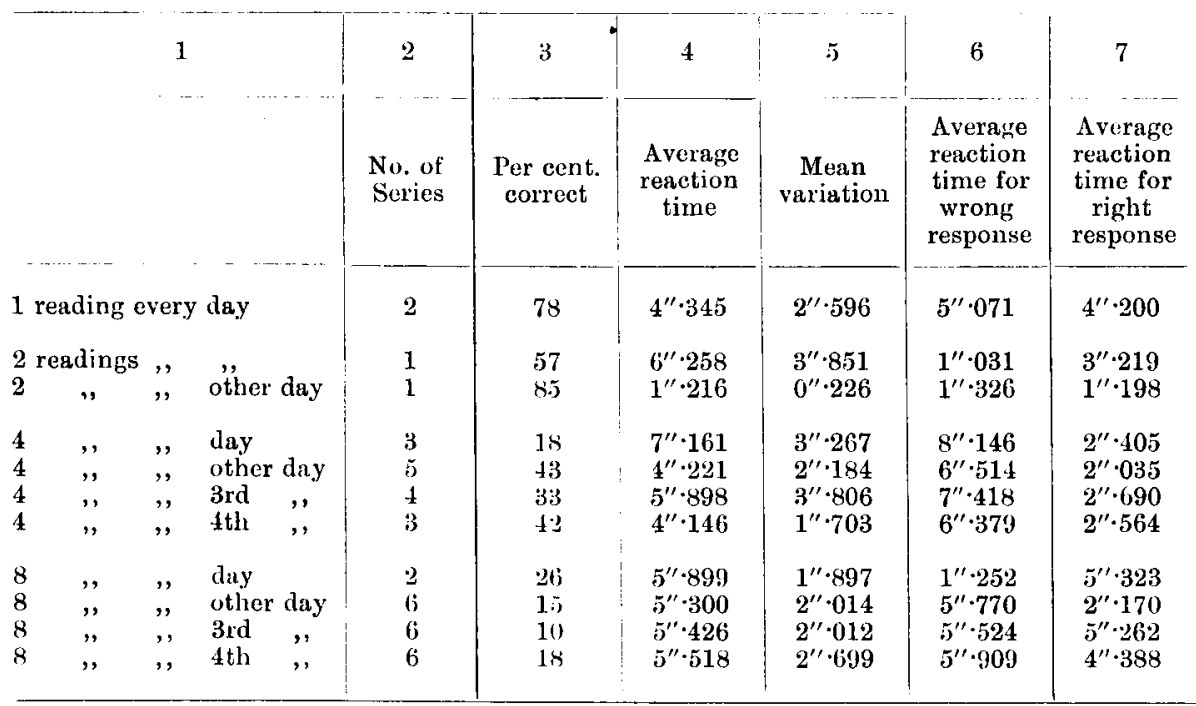

Table V. Subject $M$.

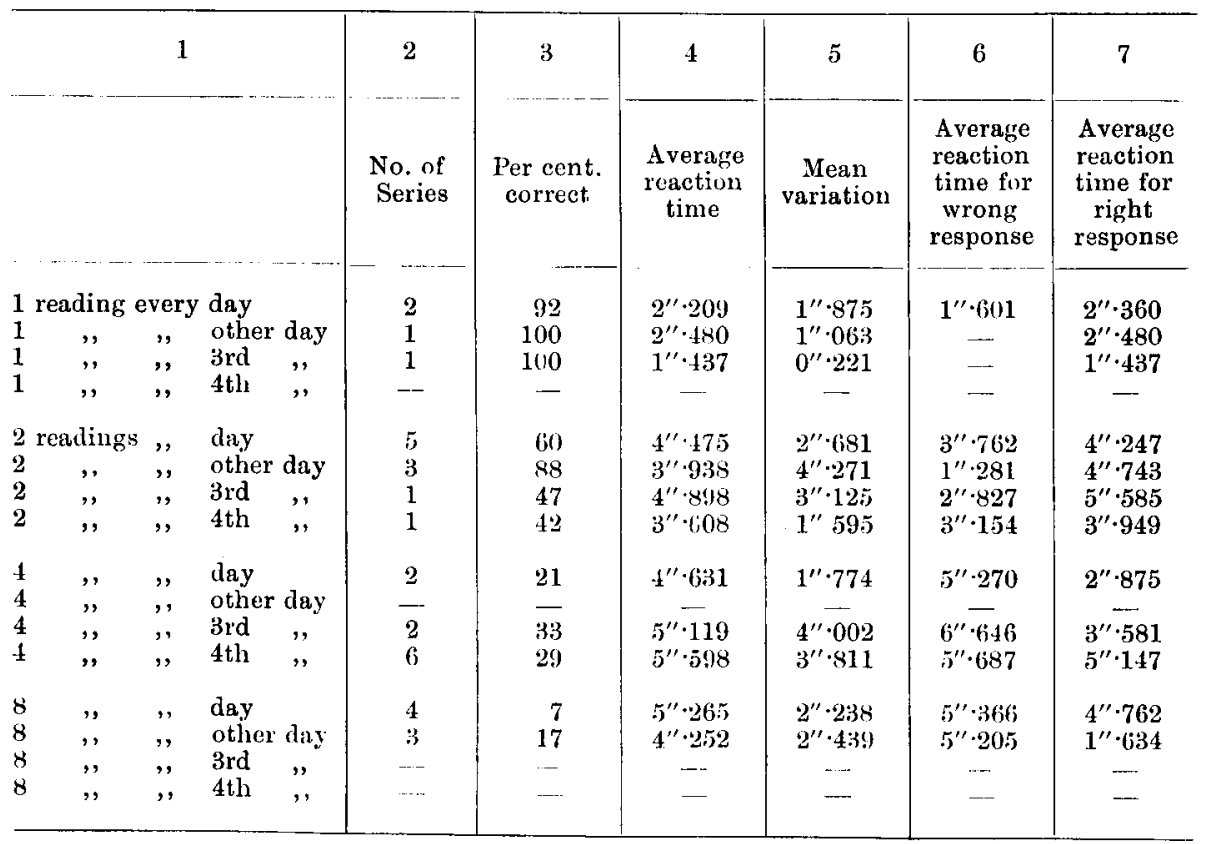


TABLE VI.

\begin{tabular}{|c|c|c|c|c|c|c|c|c|c|}
\hline \multicolumn{4}{|c|}{1} & 2 & 3 & 4 & 5 & ${ }^{6}$ & 7 \\
\hline & & & & $\begin{array}{l}\text { No. of } \\
\text { Series }\end{array}$ & $\begin{array}{l}\text { Per cent. } \\
\text { currect }\end{array}$ & $\begin{array}{l}\text { Average } \\
\text { reactionl } \\
\text { time }\end{array}$ & $\begin{array}{c}\text { Menu } \\
\text { variation }\end{array}$ & $\begin{array}{l}\text { Averace } \\
\text { reaction } \\
\text { time firr } \\
\text { wrong } \\
\text { response }\end{array}$ & $\begin{array}{l}\text { Averige } \\
\text { reaction } \\
\text { time for } \\
\text { right } \\
\text { resyonse }\end{array}$ \\
\hline $\begin{array}{l}1 \\
1 \\
1 \\
1\end{array}$ & $\begin{array}{l}\text { adiug e } \\
, " \\
, " \\
,,\end{array}$ & $\begin{array}{l}\text { every } \\
\text { ", } \\
\text { ", }\end{array}$ & $\begin{array}{l}\text { day } \\
\text { other day } \\
\text { 3rd ", } \\
\text { 4th " }\end{array}$ & $\begin{array}{r}10 \\
5 \\
4 \\
4\end{array}$ & $\begin{array}{l}79 \\
72 \\
82 \\
68\end{array}$ & $\begin{array}{l}3^{\prime \prime} \cdot 851 \\
3^{\prime \prime} \cdot 109 \\
3^{\prime \prime} \cdot 713 \\
2^{\prime \prime} \cdot 865\end{array}$ & $\begin{array}{l}2^{\prime \prime} \cdot 193 \\
1^{\prime \prime} \cdot 553 \\
1^{\prime \prime} \cdot 969 \\
2^{\prime \prime} \cdot 498\end{array}$ & $\begin{array}{l}4^{\prime \prime} \cdot 588 \\
6^{\prime \prime} \cdot 605 \\
5^{\prime \prime} \cdot 376 \\
4^{\prime \prime} \cdot 710\end{array}$ & $\begin{array}{l}3^{\prime \prime} \cdot 915 \\
2^{\prime \prime} \cdot 344 \\
2^{\prime \prime} \cdot 160 \\
2^{\prime \prime} \cdot 278\end{array}$ \\
\hline $\begin{array}{l}2 \\
2 \\
2 \\
2\end{array}$ & $\begin{array}{l}\text { dings } \\
,, \\
,\end{array}$ & $\begin{array}{l}\text { ", } \\
\ddot{\prime}\end{array}$ & $\begin{array}{l}\text { day } \\
\text { other day } \\
\text { 3rd ", } \\
\text { 4th ", }\end{array}$ & $\begin{array}{r}11 \\
8 \\
6 \\
5\end{array}$ & $\begin{array}{l}43 \\
78 \\
65 \\
45\end{array}$ & $\begin{array}{l}4^{\prime \prime} \cdot 160 \\
3^{\prime \prime} \cdot 435 \\
4^{\prime \prime} \cdot 018 \\
4^{\prime \prime} \cdot 776\end{array}$ & $\begin{array}{l}2^{\prime \prime} \cdot 852 \\
2^{\prime \prime} \cdot 723 \\
1^{\prime \prime} \cdot 389 \\
2^{\prime \prime} \cdot 744\end{array}$ & $\begin{array}{l}4^{\prime \prime} \cdot 728 \\
3^{\prime \prime} \cdot 470 \\
6^{\prime \prime} \cdot 500 \\
5^{\prime \prime} \cdot 019\end{array}$ & $\begin{array}{l}3^{\prime \prime} \cdot 478 \\
3^{\prime \prime} \cdot 100 \\
2^{\prime \prime} \cdot 818 \\
4^{\prime \prime} \cdot 505\end{array}$ \\
\hline $\begin{array}{l}\mathbf{4} \\
\mathbf{4} \\
\mathbf{4} \\
\mathbf{4}\end{array}$ & $\begin{array}{l}\text { ", } \\
", \\
",\end{array}$ & $\begin{array}{l}\text { ", } \\
",\end{array}$ & $\begin{array}{l}\text { duy } \\
\text { other day } \\
\text { 3rd ", } \\
\text { 4th ", }\end{array}$ & $\begin{array}{r}9 \\
10 \\
11 \\
14\end{array}$ & $\begin{array}{l}25 \\
33 \\
29 \\
41\end{array}$ & $\begin{array}{l}5^{\prime \prime} \cdot 754 \\
4^{\prime \prime} \cdot 135 \\
4^{\prime \prime} \cdot 923 \\
4^{\prime \prime} \cdot 927\end{array}$ & $\begin{array}{l}2^{\prime \prime} \cdot 079 \\
3^{\prime \prime} \cdot 123 \\
3^{\prime \prime} \cdot 108 \\
2^{\prime \prime} \cdot 003\end{array}$ & $\begin{array}{l}6^{\prime \prime} \cdot 149 \\
6^{\prime \prime} \cdot 061 \\
5^{\prime \prime} \cdot 840 \\
7^{\prime \prime} \cdot 101\end{array}$ & $\begin{array}{l}2^{\prime \prime} \cdot 788 \\
2^{\prime \prime} \cdot 035 \\
2^{\prime \prime} \cdot 988 \\
3^{\prime \prime} \cdot 968\end{array}$ \\
\hline $\begin{array}{l}8 \\
8 \\
8 \\
8\end{array}$ & $\begin{array}{l}\text { ", } \\
\text { ", }\end{array}$ & $\begin{array}{l}", \\
", \\
",\end{array}$ & $\begin{array}{l}\text { day } \\
\text { other day } \\
\text { 3rd " } \\
\text { 4th ", }\end{array}$ & $\begin{array}{l}10 \\
13 \\
10 \\
12\end{array}$ & $\begin{array}{r}9 \\
16 \\
11 \\
17\end{array}$ & $\begin{array}{l}5^{\prime \prime} \cdot 830 \\
5^{\prime \prime} \cdot 176 \\
4^{\prime \prime} \cdot 840 \\
5^{\prime \prime} \cdot 212\end{array}$ & $\begin{array}{c}2^{\prime \prime} \cdot 103 \\
1^{\prime \prime} \cdot 792 \\
2^{\prime \prime} \cdot 342 \\
-\end{array}$ & $\begin{array}{c}5^{\prime \prime} \cdot 731 \\
5^{\prime \prime} \cdot 364 \\
5^{\prime \prime} \cdot 507 \\
-\end{array}$ & $\begin{array}{l}5^{\prime \prime} \cdot 048 \\
3^{\prime \prime} \cdot 036 \\
3^{\prime \prime} \cdot 933 \\
4^{\prime \prime} \cdot 457\end{array}$ \\
\hline
\end{tabular}

three days, is allowed to elapse between the readings. This ability to remember more after the lapse of a few days than immediately after learning has been termed 'reminiscence' by Ballard, who has shown that it is more active among old and consolidated associations than among those recently established, and that it is accompanied by an increase in the facility (speed) of reproduction ${ }^{1}$.

4. Since Jost had shown the advantage of distribution up to two repetitions a day, we devoted ourselves to two main problems: (1) to discover if there was a limit to the degree of distribution that might be advantageous, and (2) to determine, in cases where more than one repetition was made on a single day, if learning was easier when more than one day was allowed to intervene between the groups of readings, and to discover, if possible, the most favourable interval.

The tables indicate that the highest percentage of success is obtained by the use of one reading at each sitting (see Table VI, Column 3), and, in general, the smaller the number of repetitions used at a sitting, the

1 P. B. Ballard, "Obliviscence and Reminiscence," Monogr. Suppl. II to this Journal. 
higher the percentage of success. As to the interval between sittings, the most favourable interval seems to be between two and three days for cases in which either one or two repetitions are used at a sitting; for cases in which four or eight repetitions are used at a sitting, the longer intervals of three or four days have a value equal to or greater than the shorter intervals. There are exceptions to these statements, particularly with subject A., with whom few experiments were made. But a larger number of results is necessary to determine the best interval accurately. So far as the tables show, the reaction time does not vary altogether consistently with either of the factors concerned, although the more divided readings give the shortest times in general, as do the moderate intervals.

If one accepts the law of Jost that the advantage of distributed learnings is due to the greater effectiveness of old associates for relearning, our results indicate that the process of 'consolidation' continues for at least forty-eight hours and still longer if four or more readings are made on each day. The results of permitting the hypothetical consolidation process to take place are strikingly shown by the fact that with one reading a day for sixteen days the retention after two weeks was approximately $80 \%$, while Ebbinghaus found that with accumulated repetitions sixteen readings just sufficed to learn a series of twelve syllables, so that they could be said through once without mistake. 